DOI: $10.30519 /$ ahtr.799716

Advances in Hospitality and Tourism Research (AHTR)

\title{
THE MEDIATING ROLE OF REAL-TIME INFORMATION BETWEEN LOCATION-BASED USER-GENERATED CONTENT AND TOURIST GIFT PURCHASE INTENTION
}

\author{
Mustafa R. KHAN 1 \\ University Pendidikan Sultan Idris, Malaysia \\ ORCID: 0000-0002-0250-9092 \\ Haseeb R. KHAN \\ University Pendidikan Sultan Idris, Malaysia \\ ORCID: 0000-0001-9454-6626 \\ Maya VACHKOVA \\ Leeds Trinity University, United Kingdom \\ ORCID: 0000-0002-4135-1611 \\ Arsalan M. GHOURI \\ University Pendidikan Sultan Idris, Malaysia \\ ORCID: 0000-0001-5419-8946
}

\begin{abstract}
The global use of Web 2.0 applications has generated enormous volumes of user content. Drawing on cognitive load theory, this study examines unexplored factors that influence gift purchase intention of tourists. The authors identify localization and realtime information for shaping tourists' gift purchase intention, which is facilitated by reduced cognitive overload. Analyzes of the study relies on a sample of 273 foreign tourists in Malaysia. A cross-sectional quantitative study is conducted using partial least square structural equation modeling. Results showed that location-based user-generated content and real-time information significantly affect gift purchase intention of tourists. Moreover, real-time information partially mediates the relationship between location-based user-generated content and gift purchase intention.
\end{abstract}

\author{
Article History \\ Received 24 September 2020 \\ Revised 21 January 2021 \\ Accepted 28 January 2021 \\ Available online 22 Feb. 2021 \\ Keywords \\ Web 2.0 \\ user-generated content \\ location-based content \\ real-time information \\ tourists' gift purchase intention
}

\footnotetext{
${ }^{1}$ Address correspondence to Mustafa R. Khan (Ph.D. Candidate), University Pendidikan Sultan Idris, Malaysia. E-mail: mustafa.r.khan03@gmail.com
} 


\section{INTRODUCTION}

The accelerated development of digital technologies demands changes in urban lifestyle, and a new management and production order that offers a range of technological services to the ever-elusive customer. In the current business environment, online platforms accelerate the accessibility of information to customers (Lipsman et al., 2012). Consumer-generated content exists as reviews, ratings, and opinions expressed via online platforms. Such content engages customers through increased product awareness, moreover, it is considered a valuable input for purchase decisions (Batra \& Keller, 2016; Ciftci et al., 2020). Correspondingly, the digital marketing approach is shifting from business to consumer to peerto-peer model (Akçura \& Altınkemer, 2002; Yılmaz, 2020). In this regard, consumer content sharing provides an extensive understanding of the emechanisms designed for spreading online information, which assists firms to promote and expand their business via online platforms. Consumer-toconsumer conversation embodied in reviews and opinions has become an effective marketing practice to influence consumer purchase decisions ( $\mathrm{Lu}$ et al., 2014).

Nowadays, consumers rely on the internet to find information on products and services. Moreover, consumers also share their feedbacks on products and services through online platforms (Beneke et al., 2015; Kim \& Park, 2013). A recent survey reveals that $93 \%$ of consumers used the Internet to find a local business (BrightLocal, 2020). The survey also reports that consumers' reliance on online reviews for local business has increased to $87 \%$ in 2020 , from $81 \%$ in 2019 , further, $73 \%$ of consumers seek latest reviews for decision making (BrightLocal, 2020). In transmitting information, electronic word of mouth (e-WOM) has a stronger impact than conventional word of mouth, regardless of whether the information is a positive or a negative statement about the product or service (Cheong et al., 2020; Sutanto \& Aprianingsih, 2016). Hence, businesses with positive reviews and real-time information sharing would gain potential customers searching online (BrightLocal, 2020). Therefore, user-generated content sharing on online platforms emerged as an essential source of product information (Colliander et al., 2015; Elwalda et al., 2016). Further, cloud computing technology enables different computing infrastructures to support information sharing with stakeholders, which could increase customers' interaction and enhance customer trust and purchase behavior (Langmead \& Nellore, 2018). 
The tourism industry is continuously growing and expanding (Werthner \& Ricci, 2004). Similarly, Web 2.0 online social platforms where consumers exchange their experiences of products and services are on the rise (Batra \& Keller, 2016; Ciftci et al., 2020). Location-based content and real-time data sharing are among the most prominent tools used by the tourism industry to entice customers (Berger et al., 2002; Xiang et al., 2015). Malhotra (2005) claims that the right information to the right people at the right time in real-time is required to improve performance. Thus, real-time sharing of customer satisfaction with products or services influences other customers' purchase behavior. Further, cloud computing is considered as an effective model to deliver internet services and provides many datacentric network applications (Buyya et al., 2009; Wu et al., 2018). Accordingly, online applications improve business performance with enabling customers to share information (Cibere et al., 2020).

Online applications have twofold importance to business operations. First, they allow customers to interact and share information, and second, these applications grant the business access to its customers (Buyya et al., 2009). Besides, location-based content provides information which subjective to users' profile and check-in location. The modern development of location-based information searching is getting popular to map, improve, and adhere to the processes (Margherita, 2014). Location-based searching provides relevant information to tourists by taking current location into account and offers location-based opportunities for souvenir shopping as an important tourist activity to tourists who are enthusiastic about shopping and gift purchasing (Jiang et al., 2015; Xu \& McGehee, 2012). Moreover, cloud-based social networks provide a platform where agents with mutual interests can share social knowledge and information. The integration of location elements transforms social networking as a geosocial network in which geographic location service is used to feed location base content (O'Hara et al., 2007). Accordingly, location-based content provides information for travel planning which makes tourism more enjoyable (East et al., 2017).

Advancement in internet technologies fulfills the information required for the tourism industry and offers internet applications with interactive user interfaces subjective to the location (García-Crespo et al., 2011). Hence, these applications build a bridge between tourists and the tourism industry by offering location-based information to facilitate tourists' purchase decisions. Kaplan and Haenlein (2010) highlight that Web 2.0 applications allow the creation and exchange of user-generated content, which transform word of mouth (WOM) into electronic word of 
mouth (eWOM), and potentially spread content beyond traditional audience to geographically dispersed networks (Lo et al., 2011). Furthermore, tourists trust eWOMs (Ladhari \& Michaud, 2015) and frequently rely on user-generated content as an authentic source of information (Gretzel, 2006). Additionally, a recent study reveals that $52 \%$ of users on social networking sites admitted that online content inspires their travel choices (Maria-Irina \& Istudor, 2019). Real-time data sharing captures and provides the latest information that can inform tourists in their purchase decisions. Thus, user-generated content in real-time can influence daily activities, and often guides tourists to perform efficient decisions while traveling.

International tourism continues to grow and the UNWTO forecasts a sustained increase in the future. International tourist arrivals are expected to annually increase by $3.8 \%$ in Malaysia (World Tourism Organization, 2018). While tourism in Malaysia is on the rise, studies on specific topics (e.g. location-based information, real-time information, and gift purchase intention) remain limited. Extant studies investigate the role of usergenerated content on travelers' behaviors (Tsiakali, 2018), planning (Cox et al., 2009), and brand-related dimensions (Roma \& Aloini, 2019). However, there is a scarcity of studies on location-based user-generated content (Martí et al., 2019). Furthermore, previous studies investigate tourist purchase behavior by focusing on purchasing preferences (Azmi et al., 2019), purchasing motives (Wang et al., 2010), spending patterns (Wang \& Davidson, 2010), and satisfactory purchase experience (Xu \& McGehee, 2012). Still, a limited number of studies have evaluated gift purchase decisions of tourists (Gao et al., 2017), despite it being a common practice among tourists. Tourists tend to purchase gifts from the cultural and popular destination of the host country ( $\mathrm{Li} \&$ Katsumata, 2020). For instance, approximately $70 \%$ of tourists purchased gifts for their friends and families during their travels (Litirell et al., 1994). Therefore, it is essential to investigate the likelihood of gift purchasing intention of tourists. Moreover, limited studies have explored location-based user-generated content (Bigne et al., 2021; Lu et al., 2020) and real-time data sharing (Ghouri \& Mani, 2019) to improve the likelihood of gift purchase.

Leung et al. (2013) point out that since a growing number of travelers have embraced online platforms as an effective medium for communication, collaboration, and cooperation, it is assumed that consumer-centered studies, which typically concentrate on both the use and effect of user-generated content on online platforms, may have a positive reception within the tourism industry. Considering the lack of theoretical 
and empirical findings concerning the factors that influence tourists' gift purchase intention by using online platforms, an integrated model was designed to examine the impact of location-based user-generated content on gift purchase intention of tourists. The model also exemplifies the mediating role of real-time information on the relationship between location-based user-generated content and gift purchase intention. This study did not consider the selection of a product as a gift, but instead, we aimed to investigate the role of location-based user-generated content and real-time information to facilitate the gift purchasing process.

\section{LITERATURE REVIEW}

Recently, Web 2.0 and user-generated content has reshaped the way users search, gather, develop, and interpret information. User-generated content has become an important source of information for travelers in their decision-making (Kaosiri et al., 2017; Ye et al., 2011). Goldenberg et al., (2001) suggested that user recommendations strongly influence the decision-making process of other customers. Similarly, traveler-generated content is perceived as more reliable, and authentic by other travelers than the commercial information provided by firms (Gretzel \& Yoo, 2008).

Since online platforms have contributed to increasing in usergenerated content development, users must take extra cognitive efforts to find information suitable for their task and that extra efforts lead to inferior task performance (Vessey, 1994). Cognitive load theory explains the constraints on the working memory to interpret incoming data (Sweller, 1988, 2020). Recent studies have found that intrusive content has a negative effect on users (Pfiffelmann et al., 2020; Wiese et al., 2020). When users evaluate online content, analysis is interrupted by the increasing cognitive demand that comes from the assessment task. Previous investigations have found that multiple tasks have a detrimental effect on memory only if the amount of cognitive load applied on content processing and the measuring task surpass the cognitive ability of the user (Duff \& Sar, 2015). Cognitive load theory postulates that precision in online content reduces the cognitive load of the users, thereby induce purchase decisions (Ghose \& Ipeirotis, 2006). On the other hand, cognitive load theory suggests that precise information (e.g. location-based and real-time information) reduces information overload and improves online search performance (Hollender et al., 2010; Wu \& Xie, 2018).

Previous studies have employed various information processing theories to understand the importance of user-generated content for 
tourism-related consumption. For instance, information processing theory (Liu \& Park, 2015), social information processing theory (Lim \& Heide, 2015), the elaboration likelihood model (Shin et al., 2017), and the heuristicsystematic model (Sparks et al., 2013) were all applied to gain insights on the effect of user-generated content on tourism-related consumption. There appears to be a lack of consensus on a single theoretical approach regarding the most predictive power in examining purchase likelihood of tourists. Cognitive load theory is dominantly used by researchers to explain the importance of online content to reduce cognitive load and support purchase decisions of tourists (Ghose \& Ipeirotis, 2006; Wu \& Xie, 2018; Ye et al., 2011). Cognitive load theory focuses on problem-solving in complex conditions (Sweller, 1988) and is rooted in the idea that the working capacity of individuals is limited.

Specifically, cognitive load theory implies that when interpreting new information, working memory has severe capacity and duration limitations (Sweller, 1988). Excessive information hinders the linking of information contained in memory. Information is therefore perceived to be a new input, causing more cognitive resources to be reconciled and limited cognitive capacity. On the other hand, precise information easily connects to working memory. When dealing with stored information, there are no cognitive limits on working memory (Sweller, 2020). Therefore, information processing is promoted under precise and relevant information.

Bigne et al., (2021) adopt cognitive load theory to determine the effectiveness of user-generated content on location-based online platforms i.e. TripAdvisor. Users exposed to online content rely on less effortful, more heuristic, and context-based processing strategies (Bigne et al., 2021). People optimize their capacity to make decisions by avoiding cognitive overload from information sources. Thus, individuals utilize limited and selected information to solve a problem or accomplish a task (Dan \& Reiner, 2017; Sweller, 1988). User-generated content stands out with its reliability among potential consumers. Specifically, the majority of tourists, who searching online for information, are goal-oriented (Park \& Ryu, 2019). Locationbased content and real-time information reduce information overload and improve online search performance (Hollender et al., 2010; Wu \& Xie, 2018). Relying on key on cognitive load theory, we argue that the location-based user-generated content (Bigne et al., 2021; Lu et al., 2020) and real-time information (Ghouri \& Mani, 2019) could reduce complex and excessive content to enhance the likelihood of tourists' gift purchase (Kavoura et al., 2020; Lu et al., 2020). Hence, when making consumption choices, people are likely to focus on the limited information streams coming from eWOM and 
more likely to avoid overload of online information, as irrelevant and excessive information could interrupt users' purchase decisions (Li \& Ryan, 2018; Lu et al., 2020). Hence, cognitive load theory provides a theoretical foundation for our study by suggesting that user-generated content and real-time information can facilitate gift purchase intention of tourists.

\section{Location-Based User-Generated Content and Gift Purchase Intention}

Web 2.0 applications have contributed to increased user-generated content development and location-based information has become readily popular. Online platforms, one of the features of Web 2.0 technologies, affect and stimulate social change (Sui \& Goodchild, 2011). Location-based usergenerated content provides local information, which supports planning routines and destination activities (Si et al., 2017; Väätäjä et al., 2013). Location-based user-generated content produces user-generated geospatial data which provides the opportunity for understanding users' interests, opinions, and experiences (Fischer, 2012; Monteiro et al., 2014; Vaittinen \& McGookin, 2018). It has been established that online platforms where users generate content in form of reviews, comments, and recommendations have an enormous influence on tourists' planning, traveling, and purchasing decisions (Gretzel et al., 2011). The Internet is instrumental to learning about the nature of destinations and to planning future travel (Gretzel et al., 2011; Xiang \& Gretzel, 2010). Internet users trust information provided by fellow users to evaluate products and to make a purchase decision (Lu et al., 2014).

Earlier studies have focused on souvenir purchases, shopping styles, and preferences of tourists (Azmi et al., 2019), though limited attention is paid to gift purchase intention. Gift purchasing accounts for a significant portion of tourism shopping (Anuar et al., 2017). Tourists prefer souvenirs with cultural elements such as examples of local workmanship (Li \& Cai, 2008). The most sought after souvenirs are those that represent the cultural heritage of a given destination, alongside having an overall good quality (Wilkins, 2011). User content also provides information related to culture and tourism destinations, one can acquire knowledge about culture and various geographic features (Mkono \& Tribe, 2016). Furthermore, multidimensional searching is a usual practice involved in gift purchase (Cleveland et al., 2003).

Cox et al. (2009) limit the usage of user-generated content to finding hotel reservations and destination selection. However, it is widely accepted that travelers consult online content to avoid or minimize the risk of wrong decisions (Gretzel et al., 2011; Xiang \& Gretzel, 2010). According to Lu et al. 
(2018), user-generated content often shares destination-based experiences for tourists regarding their accommodation, food, interesting spots, interaction with locals, their souvenir purchases, and how they handle an emergency. Additionally, location-based networks like TripAdvisor are highly influential in decision-making as travelers access users' content that plays a key role in their travel plans (Bigne et al., 2021; Lee et al., 2011).

Therefore, user-generated content significantly influences the choice and expectation of tourists, whereas the satisfaction level of a purchase decision is indirectly linked with the sources of content (Kaosiri et al., 2017). Additionally, Tsiakali (2018) highlights the significant effect of usergenerated content on travelers' purchase decisions. Moreover, Kavoura et al. (2020) assert that consumers rely on online content for gift purchases. Vaittinen and McGookin (2018) also report on the positive influence of online content on users' purchase decisions, however, Lu et al. (2020) warn that complex and excessive content could interrupt users' purchase decisions. Considering all this, we propose that precise location-based usergenerated content is important for obtaining information related to a tourism destination, which influences the gift purchase intention of tourists. Thus, we deduce the following hypothesis:

H1: Location-based user-generated content positively influences the gift purchase intention of tourists.

\section{Location-Based User-Generated Content and Real-Time Information}

Online content is usually categorized by location, interactivity, real-time updates, and integration with websites and computing devices (Kim et al., 2014). The concept of real-time data sharing through user-generated content is integrated to capture the latest content uploaded to the Internet in realtime (Roma \& Aloini, 2019). Hence, real-time information provides direct and timely dissemination of information, such as up-to-date information regarding travelers' reviews, opinions, and experiences (Buhalis \& Amaranggana, 2014; Yilmaz, 2018). Online platforms allow users to create and share content about their experiences and opinions (Presi et al., 2016; So et al., 2018). Due to the wide range of online networks, tourists increasingly use different online applications for information searches (BrightLocal, 2020; Li et al., 2017; Ma et al., 2017; Shankar et al., 2016), and majority of users seek out the latest reviews for decision making (BrightLocal, 2020). Tourists also share real-time experiences on different online platforms via posting pictures, videos, and reviews about purchase experiences (Shankar et al., 2016). For instance, Coca-Cola launched a 
successful campaign "Share a Coke" to encourage consumers to create a post during their purchase (Tarver, 2019). In this way, consumers' purchase experiences transform into more social experiences (Wang \& Zhang, 2012). By sharing purchase experience publicly, users build their identity on online networks (So et al., 2018), and influence purchase decisions of other users (Huang \& Benyoucef, 2013; Shankar et al., 2016). Additionally, monitoring of online content about shopping experience provides marketers with the opportunity to obtain information related to occasions, frequency, and timing of purchases. On the other hand, marketers can utilize this information in designing marketing strategies to improve both offerings and customer purchase experience (Shankar et al., 2016). Further, real-time information improves understanding of travelers' behavior ( $\mathrm{Li}$ et al., 2018) and such insights are essential in ensuring strategic policy decisions (Li et al., 2008).

Moreover, online platforms provide unprecedented opportunities for users to quickly and immediately upload and share content (Kaplan, 2012), and other users actively seek that information for their decisionmaking (Li et al., 2017). Subsequently, tourists have been seeking more sightseeing information, which means that any information that is generated and displayed digitally would need to be most recent (Kudo et al., 2019), location-based, real-time, and contextual information, hence, fully utilize intelligent technology and social innovation (Feng et al., 2019). Thus, we propose the following hypothesis:

H2: Location-based user-generated content is positively linked with real-time data sharing.

\section{Real-Time Information and Gift Purchase Intention}

The concept of real-time information has been in the limelight due to its ability to improve competitiveness (Reid, 2014), however, the recent emergence of dynamic user-provider interaction enables performance effectiveness and efficiency by dynamically engaging and performing timely actions based on real-time information (Buhalis \& Sinarta, 2019). Online platforms provide a medium for communication and thus they can be critical to attracting new customers, as well as reinforcing existing relationships between businesses and customers (Özdemir \& Çelebi, 2017; Steward et al., 2018; Yllmaz, 2020). Online platforms enable the maintenance of customers' communication records, which potentially influences other users (Ahsan \& Rahman, 2016). Technological advancement provides an opportunity to obtain real-time information of 
travelers (Yin \& Li, 2021). Prior studies on computer supported cooperative work and human-computer interaction have investigated how usergenerated content engages viewers and identified the significance of data sharing in real-time, including experiences (Piccoli, 2016), knowledge sharing (Majchrzak et al., 2013), opinions (Tsiakali, 2018), cultural museums (Özdemir \& Çelebi, 2017) and heritage (Garau, 2014). Moreover, information sharing has been considered as an important factor for improving customers' purchase behaviors (Kim \& Ko, 2012; Lee \& Whang, 2000; Mahmassani \& Jayakrishnan, 1991) and real-time interaction with customers significantly improve the motivational affordance of networks (Jung et al., 2010).

The success of information systems depends on information quality, usage, impact, and user satisfaction (DeLone \& McLean, 1992). Considering this, information systems and human-computer interaction are essential factors required for a successful web portal. Subsequently, information search is an important tool used in purchase decisions (Peter et al., 1999), and trust has been considered as an antecedent of purchase decisions (Yoon, 2002). During domestic and international travel, purchasing souvenirs whether to serve as gifts or as personal memorabilia, is one of the prominent activities of travelers of different backgrounds (Murphy et al., 2010). Moreover, bringing home souvenirs makes a trip tangible for those who receive the souvenirs as gifts or for tourists themselves by expanding their consumption of the travel experience (Gordon, 1986; Li \& Katsumata, 2020).

Subsequently, tourists rely on real-time data sharing because of its perceived transparent nature. Hence, real-time information facilitates tourists in decision-making for a specific destination ( $\mathrm{Lu}$ et al., 2018). Moreover, customers prefer real-time information for decision-making (Mahmassani \& Jayakrishnan, 1991). Fulkerson and Shank (2000) also provide evidence that real-time data sharing can enhance purchase intention. Real-time connections reveal customer preferences and behaviors and the shared behavioral response of customers significantly influences purchase behavior (Fawcett et al., 2007). Real-time information sharing is logically valuable for decision-making, as it provides travelers with recent information and improves decision-making efficiency (Dziekan \& Vermeulen, 2006; Han et al., 2020). We extend this stream of research by linking real-time information sharing and gift purchase intention. Further, a mediating role of real-time information between location-based usergenerated content and gift purchase intention may reduce excessive and irreverent content that improves users' information acquisition processes 
(Lu et al., 2020) and facilitates purchasing of souvenirs as gifts (Li \& Ryan, 2018). Thus, we hypothesize:

H3: Real-time information positively relates to the gift purchase intention of tourists.

H4: Real-time information mediates the effect of user-generated content on the gift purchase intention of tourists.

Hinging upon cognitive load theory, this research presents a model to demonstrate the direct impact of location-based user-generated content on gift purchase intention of tourists and also, depicts indirect effect through real-time information, shown in Figure 1.

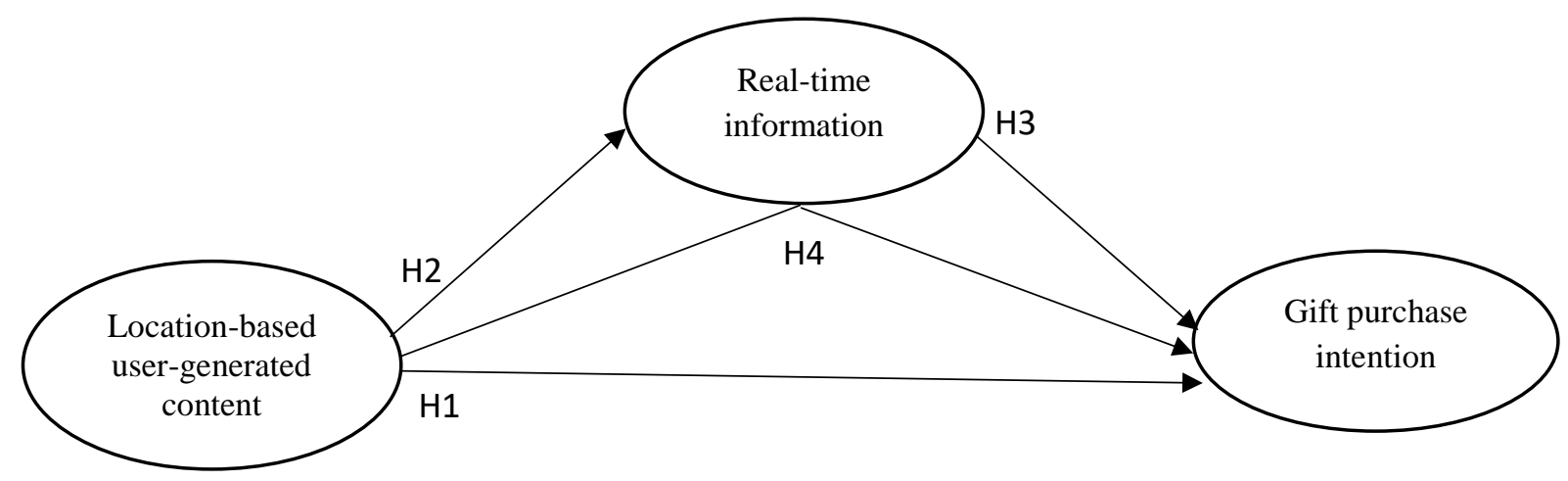

Figure 1. Research Framework

\section{METHODOLOGY}

\section{Sample}

This study benefits from engaging international tourists visiting Penang Island which coincidentally is among the most popular islands in Malaysia. For instance, only during 2019, a total of 4.16 million foreign tourists visited Penang Island (Chern et al., 2020). We applied a simple random sampling technique to select respondents. Furthermore, we collected data during the peak season of foreign tourists to ensure sample availability. We targeted foreign tourists regardless of their country of origin, they all seek information about their travel destination through the Internet. Furthermore, we ensured that our respondents were adults (over 18 years of age), that they have visited other destinations in the past, and that they had knowledge and experience of using online platforms for information search. A detailed summary of the characteristics of our respondents is shown in Table 1. 
Further, Gefen et al. (2011) a priori F-test was performed using $\mathrm{G}^{*}$ Power v.3.1.9.2 (Faul et al., 2007) to determine the minimum sample size, i.e. 176 respondents, required for empirically validating the proposed model. The data was collected between July and August 2019 by visiting Ferringhi Beach, Penang Hill, Historical Streets of George Town, and Penang Botanic Gardens. Foreign tourists were contacted randomly, they were introduced to the objectives of the study and were asked whether they were willing to participate in the survey. Upon their consent, selfadministered questionnaires were handed over to 400 respondents, a procedure that decreases the likelihood of research bias. The response rate was $68.25 \%$ which amounted to 273 questionnaire responses.

Table 1. Foreign Tourists' Characteristics

\begin{tabular}{|c|c|c|}
\hline $\begin{array}{l}\text { Demographic } \\
\text { Characteristics }\end{array}$ & Frequency & Percentage $\%$ \\
\hline \multicolumn{3}{|l|}{ Gender } \\
\hline Male & 172 & $63 \%$ \\
\hline Female & 101 & $37 \%$ \\
\hline \multicolumn{3}{|l|}{ Age } \\
\hline $18-25$ & 113 & $41.4 \%$ \\
\hline $26-30$ & 74 & $27.1 \%$ \\
\hline $31-35$ & 42 & $15.4 \%$ \\
\hline $36-40$ & 18 & $6.6 \%$ \\
\hline $41-45$ & 16 & $5.9 \%$ \\
\hline $46-50$ & 5 & $1.8 \%$ \\
\hline$>51$ & 5 & $1.8 \%$ \\
\hline \multicolumn{3}{|c|}{ Level of Education } \\
\hline School & 43 & $15.8 \%$ \\
\hline Bachelor & 166 & $60.8 \%$ \\
\hline Master & 60 & $22 \%$ \\
\hline $\mathrm{PhD}$ & 4 & $1.5 \%$ \\
\hline \multicolumn{3}{|c|}{ Use of the Internet for } \\
\hline \multicolumn{3}{|c|}{ Information Access } \\
\hline \multicolumn{3}{|c|}{ About Destinations } \\
\hline Always & 148 & $54.2 \%$ \\
\hline Very Frequently & 77 & $28.3 \%$ \\
\hline Occasionally & 46 & $16.8 \%$ \\
\hline Rarely & 2 & $0.7 \%$ \\
\hline \multicolumn{3}{|l|}{ Stay in Penang } \\
\hline$<2$ Night & 23 & $8.4 \%$ \\
\hline 2-3 Nights & 167 & $61.2 \%$ \\
\hline 4-5 Nights & 55 & $20.1 \%$ \\
\hline$>5$ Nights & 28 & $10.3 \%$ \\
\hline
\end{tabular}




\section{Assessment of Measurement Model}

We used the scale developed by Feng et al. (2016) to measure location-based user-generated content. Location-based content identifies users' geographical position and increases the relevance of content to other users. The scale consists of three items, which are related to the precise value of location-based information to users. The gift purchase intention construct was measured by using the scale developed by Putrevu and Lord (1994) and Taylor and Baker (1994). The scale consists of five items including a reverse question that investigates gift purchase intention of foreign tourists with a stronger agreement with each item. In a recent study, Lu et al. (2014) revalidated the measurement scale for purchase intention in the context of online users. Real-time information sharing is a construct adopted from Ghouri and Mani (2019) and it consists of three items. Respondents were asked about the advantage, usefulness, and significance of real-time information. The questionnaire was based on a five-point Likert scale from 1 = strongly disagree to $5=$ strongly agree. The analytical results of measurement model obtained for validity and reliability of each construct fulfill the recommended criteria for all factors, AVE is $>0.50$, the value of Jöreskog's rho (Qc) and Cronbach's alpha $(\alpha)$ are $>0.70$ (Hair et al., 2019; Henseler et al., 2015) reflecting internal consistency and reliability, results shown in Table 2.

Table 2. Results of Measurement Model

\begin{tabular}{|c|c|c|c|c|c|c|c|c|}
\hline Construct & Source & Item & $\begin{array}{c}\text { Codin } \\
\mathrm{g}\end{array}$ & Loading & VIF & Qc & $\alpha$ & AVE \\
\hline \multirow{5}{*}{$\begin{array}{l}\text { Gift } \\
\text { Purchase } \\
\text { Intention }\end{array}$} & \multirow{5}{*}{$\begin{array}{c}\text { Lu et al. } \\
\text { (2014); } \\
\text { Putrevu } \\
\text { and Lord } \\
\text { (1994); } \\
\text { Taylor and } \\
\text { Baker } \\
\text { (1994) }\end{array}$} & $\begin{array}{l}\text { I would consider buying the } \\
\text { user recommended gift. }\end{array}$ & GPI1 & 0.843 & 2.686 & \multirow{5}{*}{0.876} & \multirow{5}{*}{0.874} & \multirow{5}{*}{0.665} \\
\hline & & $\begin{array}{l}\text { I have no intention to buy the } \\
\text { user recommended gift. }\end{array}$ & GPI2 & 0.857 & 2.774 & & & \\
\hline & & $\begin{array}{l}\text { It is possible that I would buy } \\
\text { users' recommended gifts. }\end{array}$ & GPI3 & 0.838 & 2.785 & & & \\
\hline & & $\begin{array}{l}\text { I will purchase the user } \\
\text { recommended gift also in next } \\
\text { trip. }\end{array}$ & GPI4 & 0.783 & 1.767 & & & \\
\hline & & $\begin{array}{l}\text { If I am in need, I would buy } \\
\text { the user recommended gift. }\end{array}$ & GPI5 & 0.752 & 2.092 & & & \\
\hline \multirow{4}{*}{$\begin{array}{l}\text { Location- } \\
\text { based User- } \\
\text { generated } \\
\text { Content }\end{array}$} & \multirow{4}{*}{$\begin{array}{l}\text { Feng et al. } \\
\quad(2016)\end{array}$} & in a certain situation. & & & & \multirow{4}{*}{0.804} & \multirow{4}{*}{0.801} & \multirow{4}{*}{0.717} \\
\hline & & $\begin{array}{l}\text { I would view user-generated } \\
\text { content related to me being in } \\
\text { a specific location as useful. }\end{array}$ & LBC2 & 0.902 & 2.407 & & & \\
\hline & & $\begin{array}{l}\text { Location-based user- } \\
\text { generated content can provide }\end{array}$ & & & & & & \\
\hline & & $\begin{array}{l}\text { additional information-based } \\
\text { on real-time location more } \\
\text { quickly and accurately. }\end{array}$ & LBC3 & 0.787 & 1.463 & & & \\
\hline
\end{tabular}




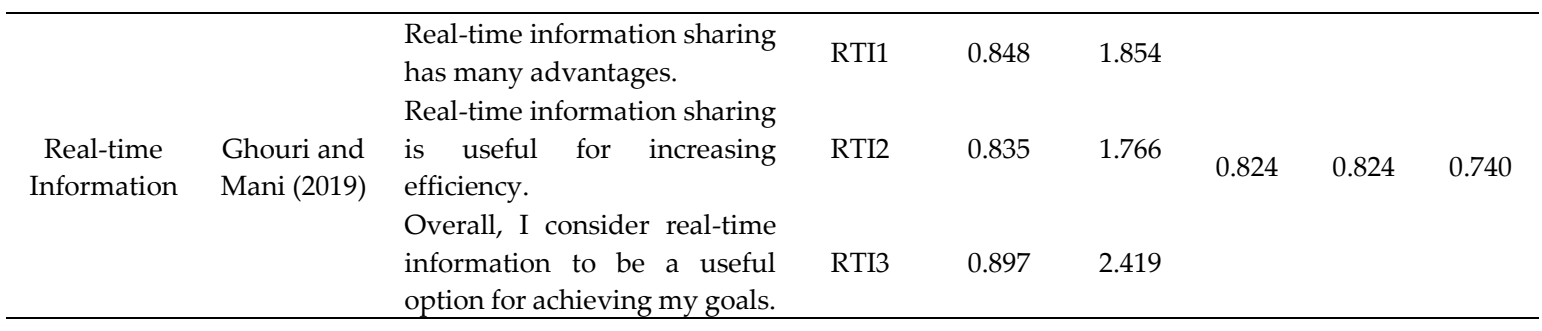

To determine non-response bias, independent t-tests method was performed by comparing the first and the last 25 responses for all constructs (Armstrong \& Overton, 1977; Ghouri \& Mani, 2019). The results showed an insignificant difference between the early 25 and late 25 responses, which reveals non-response bias. Besides, a common method bias test was conducted by using the collinearity approach (Kock, 2017; Podsakoff et al., 2003). The results revealed a satisfactory value for the variance inflation factor $(\mathrm{VIF})<3$. Thus, we established that there is no common method bias problem. Finally, all variables of the model were tested for discriminant validity. We examine discriminant validity using "Heterotrait-Monotrait" criterion (HTMT), shown in Table 3. The results revealed that the HTMT value is smaller than 0.90, which fulfills the required criteria (Henseler et al., 2015). Thus, the model revealed satisfactory results for discriminant validity.

Table 3. Heterotrait-Monotrait Criterion

\begin{tabular}{lccc}
\hline Construct & GPI & LBC & RIT \\
\hline Gift Purchase Intention (GPI) & & & \\
Location-based User-generated Content (LBC) & 0.738 & & \\
Real-time Information (RIT) & 0.678 & 0.611 & \\
\hline
\end{tabular}

\section{Assessment of Structural Model}

We employed the SmartPLS version 3.3.2 to examine the Structural Equation Modelling (SEM) technique using the Partial Least Squares (PLS) algorithm. The standardized root means squared residual (SRMR) and the normed fit index (NFI) were used for goodness of fit (Henseler et al., 2016). The SRMR value 0.070 was successfully obtained by the model, which fulfills a certain threshold value of $<0.08$. Further, the NFI value 0.917 was obtained for the model, which fulfills the required threshold criteria $>0.90$ (Henseler et al., 2016), hence empirical data perfectly fit the model. Further, the variance inflation factor (VIF) was calculated for all paths. The obtained VIF values for all paths were below the threshold criteria of 5 , thus, found no indication of multicollinearity (Hair et al., 2019). The coefficient of 
determination $\left(\mathrm{R}^{2}\right)$ has demonstrated moderate explanatory power of the model, obtained $R^{2}$ value 0.479 reveals that 47.9 percent of the variance in gift purchase intention is explained by the model. The value of StoneGeisser's $\mathrm{Q}^{2}$ is obtained through the blindfolding procedure for the model. The obtained value 0.311 demonstrates that the model consists of predictive relevance as it is higher than 0 (Geisser, 1974; Stone, 1974).

Table 4 demonstrates the results of the structural model. Results reveal the existence of significant positive relationship between locationbased user-generated content and gift purchase intention where $\beta=0.440$, $\mathrm{t}$-value $=6.981, \mathrm{p}$-value $=0.000$ and $\mathrm{f}^{2}=0.280$, which is in support of H1. Additionally, finding reports that location-based user-generated content have significant positive relation with real-time information where $\beta=$ 0.497, $\mathrm{t}$-value $=8.942$, $\mathrm{p}$-value $=0.000$ and $\mathrm{f}^{2}=0.329$ and real-time information also have significant positive relation with gift purchase intention, where $\beta$ $=0.358$, $\mathrm{t}$-value $=5.409$, and $\mathrm{p}$-value $=0.000$ and $\mathrm{f}^{2}=0.185$, supporting $\mathrm{H} 2$ and $\mathrm{H} 3$ respectively. Figure 2 demonstrates the final model and visual summary of results for hypothesis testing.

Table 4. Structural Model

\begin{tabular}{|c|c|c|c|c|c|c|c|c|c|c|c|}
\hline Effect & $\beta$ & $\begin{array}{c}\text { CI (5\%, } \\
95 \%)\end{array}$ & SE & t-value & p-value & $\mathbf{f}^{2}$ & VIF & $\mathbf{R}^{2}$ & $\mathrm{Q}^{2}$ & SRMR & NFI \\
\hline LBC -> GPI & 0.440 & $\begin{array}{l}(0.336 \\
0.539)\end{array}$ & 0.063 & 6.981 & 0.000 & 0.280 & 1.329 & 0.479 & 0.311 & 0.070 & 0.917 \\
\hline LBC-> RTI & 0.497 & $\begin{array}{l}(0.404, \\
0.587)\end{array}$ & 0.056 & 8.942 & 0.000 & 0.329 & 1.000 & 0.247 & 0.178 & & \\
\hline RTI -> GPI & 0.358 & $\begin{array}{l}(0.252, \\
0.473)\end{array}$ & 0.066 & 5.409 & 0.000 & 0.185 & 1.329 & & & & \\
\hline
\end{tabular}

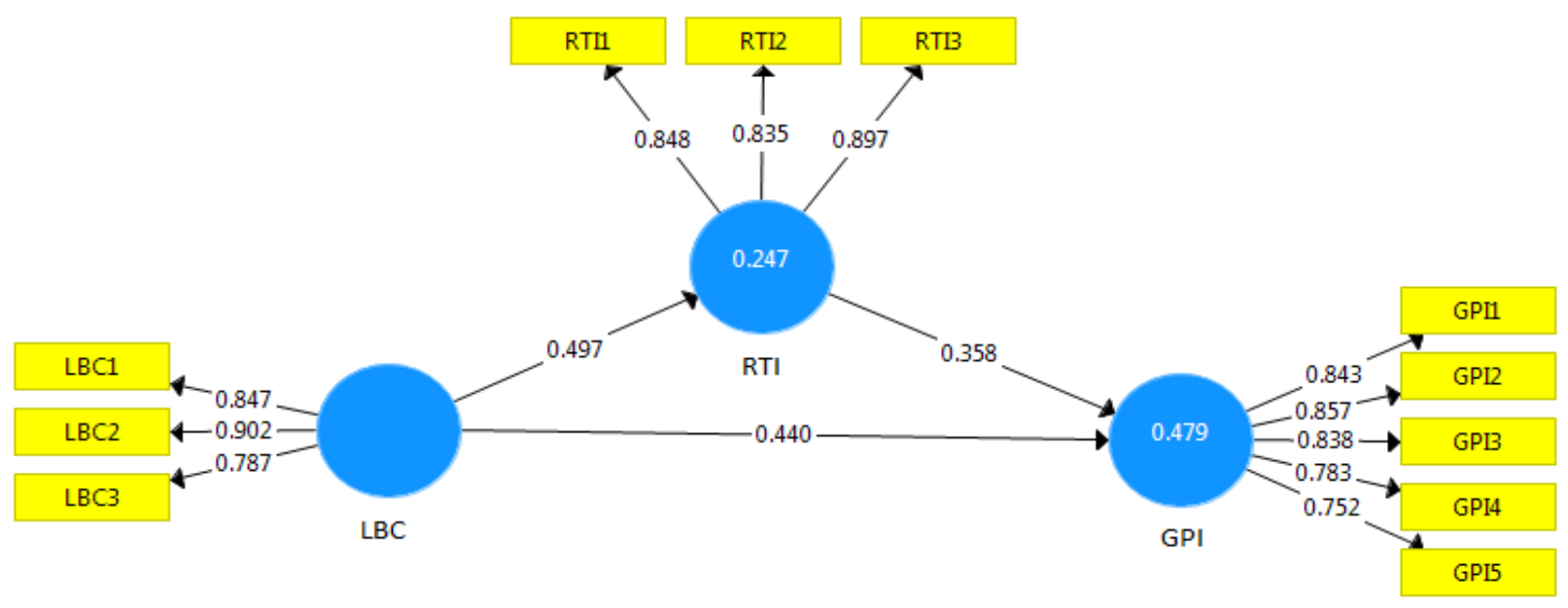

Figure 2. Results of Research Model 


\section{Mediation Analysis}

This study applied Nitzl et al.'s (2016) analytical approach in conducting mediation analysis. Results of mediation analysis revealed that the values of $95 \%$ bias-corrected confidence interval (BCCI) did not straddle a 0 in between, which indicates the existence of mediating effect of real-time information, shown in Table 5. Further, to determine the degree of mediation i.e. partial or full, the variance accounted for (VAF) index was used to examine the size of the indirect effect (LBC -> RTI $->$ GPI) related to the total effect (LBC -> GPI). The results reveal the existence of partial mediation, as the resulting VAF value of 28.8 percent fall within the range of 20-80 percent, which supported H4. Hence, the finding concludes that real-time information partially mediates the relationship between locationbased user-generated content and gift purchase intention.

Table 5. Mediation Analysis

\begin{tabular}{ccccccccc}
\hline $\begin{array}{c}\text { Total } \\
\text { Effect }\end{array}$ & $\boldsymbol{\beta}$ & $\begin{array}{c}\mathbf{t}- \\
\text { value }\end{array}$ & $\begin{array}{c}\text { BCCI (5 } \\
\mathbf{\%}, \mathbf{9 5} \%)\end{array}$ & $\begin{array}{c}\text { Indirect } \\
\text { Effect }\end{array}$ & $\boldsymbol{\beta}$ & $\begin{array}{c}\mathbf{t}- \\
\text { value }\end{array}$ & $\begin{array}{c}\text { BCCI (5 \%, } \\
\mathbf{9 5 \%})\end{array}$ & VAF \\
\hline LBC -> GPI & $0.618^{*}$ & 13.674 & $\begin{array}{c}(0.534, \\
0.681)\end{array}$ & $\begin{array}{c}\text { LBC - RTI- } \\
>\text { GPI }\end{array}$ & $0.178^{*}$ & 4.755 & $(0.126,0.245)$ & $28.8 \%$ \\
\hline
\end{tabular}

*Significant at $\mathrm{p} \leq 0.001$

\section{DISCUSSION}

It is widely accepted that tourists rely on online content as an important source of information (Kaosiri et al., 2017; Ye et al., 2011). Mkono and Tribe (2016) affirm that user-generated content provides information related to culture and features of a given tourism destination. The authors also argue that user-generated content can also popularise locations and tourist memorabilia such as souvenirs of specific locations (Bigne et al., 2021; Lu et al., 2018), which in turn leads to influence gift purchase intention of other tourists (Kavoura et al., 2020; Li \& Katsumata, 2020; Tsiakali, 2018).

The results of this study reveal that location-based user-generated content has a significant relationship with gift purchase intention among tourists. In line with cognitive load theory, location-based user-generated content reduce effort of tourists searching online information (BrightLocal, 2020; Li et al., 2017; Ma et al., 2017; Shankar et al., 2016) by providing context-based information (Bigne et al., 2021). Hence, location-based usergenerated content reduces the cognitive load of tourists by providing valuable suggestions, thereby influencing gift purchase intention of tourists (Ghose \& Ipeirotis, 2006; Wu \& Xie, 2018). These results seem logical and 
come in line with related studies (Kaosiri et al., 2017; Lee et al., 2011; Tsiakali, 2018) which affirm that user-generated content significantly influences choices, expectations, and purchases of tourists in different tourism destinations. This justifies why travelers initiate planning by online information searches that predate making any decisions (Gretzel et al., 2011; Xiang \& Gretzel, 2010). During the data collection process, we observed that the majority of tourists about $82.5 \%$ frequently use the Internet for information access about destinations, which is similar to a local consumer review survey that reveals $93 \%$ of consumers used the internet to find a local business (BrightLocal, 2020). Additionally, results support that consumers paid attention to online content for gift purchase decisions (Kavoura et al., 2020). Results also support researchers who point out tourists' involvement in multi-dimensional information searching related to product overall quality, destination representation ability, workmanship, and cultural expression for gift purchasing (Cleveland et al., 2003; Li \& Cai, 2008).

We report a positive relationship between location-based usergenerated content and real-time information. The results show that location-based user-generated content and real-time information not only improve tourists' goal-oriented search performance but also reduce information search time and cognitive effort (Hollender et al., 2010; Park \& Ryu, 2019; Wu \& Xie, 2018). When tourists are browsing online for information, location-based user-generated content restricts excessive and irrelevant information and real-time information provides latest and updated search outcomes. Additionally, tourists have been seeking more sightseeing information, which means that any information that is generated and displayed digitally would need to be recent (Kudo et al., 2019). On the other hand, the outcome and process of users' information searches can be negatively affected by irrelevant information. Therefore, providing relevant information is crucial to reduce cognitive overload in online environments by utilizing intelligent technology and social innovation (Feng et al., 2019).

The present study also found a positive relationship between realtime information and gift purchase intention. The recent emergence of dynamic user-provider interaction enables performance effectiveness and efficiency by dynamically engaging and performing timely actions based on real-time information (Buhalis \& Sinarta, 2019). Technological advancement provides an opportunity to obtain real-time information of travelers (Yin \& Li, 2021) to facilitate users with the latest information across online platforms for gift purchase decisions (Kavoura et al., 2020). 
Therefore, business managers should engage and encourage customers for positive e-WOM about products and services (Cheong et al., 2020; Sutanto \& Aprianingsih, 2016) to improve business positive reviews and real-time information sharing would engage potential customers searching online (BrightLocal, 2020).

Further, the results reveal the significance of real-time information in mediating the relationship between location-based user-generated content and the gift purchase intention of tourists. Real-time information sharing is logically valuable for decision-making, as it provides travelers with recent information and improves decision-making efficiency (Dziekan \& Vermeulen, 2006; Han et al., 2020). It has been established that tourists search for online information with a task-directed purpose (Park \& Ryu, 2019). Real-time information improves information reception ( $\mathrm{Lu}$ et al., 2020) by providing up-to-date content (Berger et al., 2002). Hence, real-time information as a mediator reduces excessive content, which in turn improves users' information acquisition processes (Lu et al., 2020) and online search performance (Hollender et al., 2010; Wu \& Xie, 2018) thereby facilitating the decision-making process behind gift purchasing (Kavoura et al., 2020; Li \& Ryan 2018). In support of our study, a local consumer review survey also highlighted that $73 \%$ of users seek latest and real-time information for decision making (BrightLocal, 2020). Whereas, intrusive content negatively affects users (Pfiffelmann et al., 2020; Wiese et al., 2020). Based on cognitive load theory, the study provides evidence that real-time information reduces information overload by providing updated and latest location-based content could significantly influence gift purchase intention of tourists (Dan \& Reiner, 2017; Hollender et al., 2010; Wu \& Xie, 2018). These findings are in line with previous studies, which highlight the significance of precise content for tourist decision-making in terms of sightseeing information and general itinerary planning (Feng et al., 2019; Kudo et al., 2019; Roma \& Aloini, 2019). A similar has been confirmed by researchers, who asserted that travelers need information in real-time to enhance purchase decision efficiency (Dziekan \& Vermeulen, 2006; Fulkerson \& Shank, 2000).

Therefore, our study contributes to the literature by advancing knowledge about the significance of location-based content and providing evidence of real-time information to facilitate tourists at different travel destinations in the novel context of the gift purchase decision. 


\section{Theoretical Implications}

This research aims to address the lack of knowledge on the influence of location-based and real-time content on gift purchase intention of tourists. The nature of gift purchasing makes it difficult for tourists to evaluate and purchase gifts with cultural expression or representation of destination (Li \& Cai, 2008; Wilkins, 2011). First, the study contributes to knowledge development in tourism by revealing location-based user-generated content as an antecedent of gift purchase intention of tourists. Second, the study opens new avenues for research on this promising topic, especially the application of real-time information to the field of tourism destinations. Previous studies (Feng et al., 2019; Lee et al., 2011; Lu et al., 2014) have examined location-based content, however, no study has attempted to examine the relationship between location-based user-generated content with gift purchase intention of tourists.

Tourists rely on real-time information for making their consumption decisions while abroad (Lu et al., 2018). Previous studies (Kudo et al., 2019; Roma \& Aloini, 2019) have examined real-time information however no study has attempted to examine mediation of real-time information between location-based user-generated content and gift purchase intention of tourists.

Hence, our study addresses the lack of knowledge in this area and demonstrates that location-based user-generated content is positively linked with real-time information and significantly influences gift purchase intention of tourists. Perhaps more importantly, real-time information can function to reduce information overload and improve online search performance (Hollender et al., 2010; Wu \& Xie, 2018). Therefore, the integration of real-time information in user-generated content provides tourists with the benefit of the latest content shared on the Internet. This in turn reduces cognitive load and improves the efficiency of tourist gift purchase decisions.

\section{Managerial Implications}

Currently, the tourism industry is experiencing dramatic growth and destination managers are motivated to better engage potential tourists. In this regard, our findings provide important managerial implications. Tourists prefer gifts that exemplify local culture and represent their travel destination (Gordon, 1986; Li \& Katsumata, 2020). Thus, an innovative marketing approach is required for these products to reach tourists. 
Developments in digital technologies have presented new and advanced means of marketing to business managers (Yllmaz, 2020). The emergence of Web 2.0 and online platforms influence the intention of tourists and impact marketing models that organizations should transform to expand their business. In presence of intelligent technology and social innovation (Feng et al., 2019), users paid attention to online content for gift purchase decisions (Kavoura et al., 2020) and majority of users seek latest reviews for decision making (BrightLocal, 2020). Hence, managers could benefit from the insight that the gift purchase decisions of many tourists will be strongly influenced by online information. This study reports that user-generated content has a significant impact on the gift purchase intention of tourists, while positive content has the potential to boost sales. This implies that cultural and destination products providers should deliver more resources to improve the valence of their consumer reviews. Further useful strategies would be to stimulate positive content sharing about product/service (Cheong et al., 2020; Sutanto \& Aprianingsih, 2016) through customer engaging campaigns such as "Share a Coke" launched by Coca Cola (Tarver, 2019) and provide incentives to encourage consumers to create a post during their purchase. Such campaigns that urge consumers to share real-time information are likely to raise awareness and to increase the sales of cultural workmanship products.

It has been established that tourists share their experiences via different online platforms by way of posting pictures, videos, and reviews about purchases (Buhalis \& Sinarta, 2019; Shankar et al., 2016). On the other hand, these online platforms become an important source for international travelers who seek advice, which ultimately influences their gift purchase intention (Kavoura et al., 2020; Park \& Ryu, 2019). Online content can pass a strong sense of destinations interesting features to travelers, and, more importantly, contain valuable cultural experiences. User generated content could, therefore, help managers to improve and expand their business. Further, several mediums of online communication are available, such as websites, blogs, information databases, online forums, and virtual communities, which could all be effective ways for customer relationship management. Hence, online platforms serve as a major communication channel between business and consumers, practitioners should set up an effective strategy to make available destination information more quickly and accurately, thereby, avail an opportunity to feed travelers' destination information, which result in additional future businesses. Thus, this study provides support to the tourism industry and local businesses to adopt location-based agile online marketing approaches for creating real-time 
value and mechanisms to establish dynamic engagement with customers to gain tourists search online for gift purchasing (BrightLocal, 2020; Kavoura et al., 2020; Park \& Ryu, 2019).

\section{CONCLUSION}

The present study provides important insights into the underlying mechanisms through which location-specific user content impacts gift purchase intentions of other consumers. We offer empirical evidence of the predicting role user-generated content plays in gift purchasing. Furthermore, this study proposes a model exemplifying tourists' gift purchase intentions and the importance of online information contextualized by location, authorship of other users as well as time. We conclude that location-based user-generated content is an antecedent of tourists' gift purchase intention. Moreover, the sharing of real-time information mediates the relationship between location-based usergenerated content and tourists' gift purchase intention. In light of the scarcity of empirical studies on location-based user-generated content (Martí et al., 2019) and gift purchasing of tourists (Gao et al., 2017), current study advances the literature on tourist consumption, online customer engagement, and electronic word of mouth. Thus, we hope that this work will inspire future inquiries in these inter-related fields of scholarship.

\section{Limitations and Future Research Directions}

Despite its important theoretical and managerial contributions, this study has several limitations that may offer opportunities for future research. First, survey respondents were foreign tourists visiting Penang Island, Malaysia. Though respondents were online platform users, the findings would be more precise if respondents from several states will include in the sample. Second, this study does not consider variances in respondent backgrounds. Digital technology is becoming a worldwide phenomenon; thus, a cross-cultural study of tourist responses to location-based online content could be a promising new research direction. Third, this study does not account for any specific online platform. Future research should incorporate the role of online platforms (e.g. social media, SaaS, Web 2.0) to provide a comprehensive understanding of tourists' gift purchase intention. Fourth, future studies may use other variables such as tourists' attitudes, trust, and motivation with our research framework to provide new research insight. 


\section{REFERENCES}

Ahsan, K., \& Rahman, S. (2016). An investigation into critical service determinants of customer to business (C2B) type product returns in retail firms. International Journal of Physical Distribution \& Logistics Management, 46(6/7), 606-633.

Akçura, M. T., \& Altınkemer, K. (2002). Diffusion models for B2B, B2C, and P2P exchanges and e-speak. Journal of Organizational Computing and Electronic Commerce, 12(3), 243-261.

Anuar, F. I., Yulia, A., Hamden, H. N. B., Aziz, K. F. B. A., \& Edruce, S. M. B. W. H. (2017). Exploring the rationales of souvenir purchase behaviour and roles of behavioural belief and perceived authenticity among international tourists in Malaysia. In A. Saufi, I. Andilolo, N. Othman, \& A. Lew (Eds), Balancing Development and Sustainability in Tourism Destinations (pp. 79-87). Singapore: Springer.

Armstrong, J. S., \& Overton, T. S. (1977). Estimating nonresponse bias in mail surveys. Journal of Marketing Research, 14(3), 396-402.

Azmi, A., Buliah, A. L., Ramaiah, A. K., Ariffin, H. F., \& Ngelambong, A. (2019). Tourist shopping styles and preferences in Kuala Lumpur, Malaysia. In A. Mat Noor, A. Mohd Zakuan, \& S. Muhamad Noor (Eds.), Proceedings of the Second International Conference on the Future of ASEAN (ICoFA) 2017: Vol. 1 (pp. 91-102). Singapore: Springer.

Batra, R., \& Keller, K. L. (2016). Integrating marketing communications: New findings, new lessons, and new ideas. Journal of Marketing, 80(6), 122-145.

Beneke, J., Mill, J., Naidoo, K., \& Wickham, B. (2015). The impact of willingness to engage in negative electronic word-of-mouth on brand attitude: A study of airline passengers in South Africa. Journal of Business and Retail Management Research, 9(2), 68-84.

Berger, S., Lehmann, H., \& Lehner, F. (2002). Location-based services in the tourist industry. Information Technology \& Tourism, 5(4), 243-256.

Bigne, E., Simonetti, A., Ruiz, C., \& Kakaria, S. (2021). How online advertising competes with user-generated content in TripAdvisor. A neuroscientific approach. Journal of Business Research, 123, 279-288.

BrightLocal (2020, December 9), Local Consumer Review Survey 2017. Retrieved December 13, 2020, from https://www.brightlocal.com/research/local-consumer-reviewsurvey/\#Q8

Buhalis, D., \& Amaranggana, A. (2014). Smart tourism destinations. In Z. Xiang \& I. Tussyadiah (Eds.), Information and Communication Technologies in Tourism 2014 (pp. 553-564). Vienna, Austria: Springer.

Buhalis, D., \& Sinarta, Y. (2019). Real-time co-creation and nowness service: lessons from tourism and hospitality. Journal of Travel \& Tourism Marketing, 36(5), 563-582.

Buyya, R., Yeo, C. S., Venugopal, S., Broberg, J., \& Brandic, I. (2009). Cloud computing and emerging IT platforms: Vision, hype, and reality for delivering computing as the 5th utility. Future Generation Computer Systems, 25(6), 599-616.

Cheong, J. W., Muthaly, S., Kuppusamy, M., \& Han, C. (2020). The study of online reviews and its relationship to online purchase intention for electronic products among the millennials in Malaysia. Asia Pacific Journal of Marketing and Logistics, 32(7), 15191538.

Cibere, G. U., Başaran, M., \& Kantarci, K. (2020). Evaluation of hotel performance attributes through consumer generated reviews: The case of Bratislava. Advances in Hospitality and Tourism Research, 8(1), 48-75. 
Ciftci, O., Berezina, K., Cavusoglu, M., \& Cobanoglu, C. (2020). Winning the battle: The importance of price and online reviews for hotel selection. Advances in Hospitality and Tourism Research, 8(1), 177-202. https://doi.org/10.30519/ahtr.528150

Cleveland, M., Babin, B. J., Laroche, M., Ward, P., \& Bergeron, J. (2003). Information search patterns for gift purchases: A cross-national examination of gender differences. Journal of Consumer Behaviour, 3(1), 20-47.

Colliander, J., Dahlén, M., \& Modig, E. (2015). Twitter for two: Investigating the effects of dialogue with customers in social media. International Journal of Advertising, 34(2), 181-194.

Cox, C., Burgess, S., Sellitto, C., \& Buultjens, J. (2009). The role of user-generated content in tourists' travel planning behavior. Journal of Hospitality Marketing \& Management, 18(8), 743-764.

Dan, A., \& Reiner, M. (2017). EEG based analysis of cognitive load enhance instructional analysis. Journal of Educational Data Mining, 9(2), 31-44.

DeLone, W. H., \& McLean, E. R. (1992). Information systems success: The quest for the dependent variable. Information Systems Research, 3(1), 60-95.

Chern, L. T., Pfordten D., \& Devi, V. (2020, January 2). Penang expects airport to record 8.3 million tourist arrivals. The Star. Retrieved December 13, 2020, from: https://www.thestar.com.my/news/nation/2020/01/02/penang-expects-airport-torecord-83-million-tourist-arrivals

Duff, B. R. L., \& Sar, S. (2015). Seeing the big picture: Multitasking and perceptual processing influences on ad recognition. Journal of Advertising, 44(3), 173-184.

Dziekan, K., \& Vermeulen, A. (2006). Psychological effects of and design preferences for real-time information displays. Journal of Public Transportation, 9(1), 1-19.

East, D., Osborne, P., Kemp, S., \& Woodfine, T. (2017). Combining GPS \& survey data improves understanding of visitor behaviour. Tourism Management, 61, 307-320.

Elwalda, A., Lü, K., \& Ali, M. (2016). Perceived derived attributes of online customer reviews. Computers in Human Behavior, 56, 306-319.

Faul, F., Erdfelder, E., Lang, A. G., \& Buchner, A. (2007). G* Power 3: A flexible statistical power analysis program for the social, behavioral, and biomedical sciences. Behavior Research Methods, 39(2), 175-191.

Fawcett, S. E., Osterhaus, P., Magnan, G. M., Brau, J. C., \& McCarter, M. W. (2007). Information sharing and supply chain performance: The role of connectivity and willingness. Supply Chain Management an International Journal, 12(5), 358-368.

Feng, B., Ye, Q., \& Collins, B. J. (2019). A dynamic model of electric vehicle adoption: The role of social commerce in new transportation. Information $\mathcal{E}$ Management, 56(2), 196-212.

Feng, X., Fu, S., \& Qin, J. (2016). Determinants of consumers' attitudes toward mobile advertising: The mediating roles of intrinsic and extrinsic motivations. Computers in Human Behavior, 63, 334-341.

Fischer, F. (2012). VGI as big data: A new but delicate geographic data-source. GeoInformatics, 15(3), 46-47.

Fulkerson, B., \& Shank, M. (2000). The new economy electronic commerce, and the rise of mass customization. In M. Shaw, R. Blanning, R. Strader, \& A. Whinston (Eds.). Handbook on electronic commerce (pp. 411-430). Heidelberg: Springer-Verlag Berlin Heidelberg.

Gao, H., Huang, S. S., \& Brown, G. (2017). The influence of face on Chinese tourists' gift purchase behaviour: The moderating role of the gift giver-receiver relationship. Tourism Management, 62, 97-106. 
Garau, C. (2014). From territory to smartphone: Smart fruition of cultural heritage for dynamic tourism development. Planning Practice and Research, 29(3), 238-255.

García-Crespo, Á., López-Cuadrado, J. L., Colomo-Palacios, R., González-Carrasco, I., \& Ruiz-Mezcua, B. (2011). Sem-Fit: A semantic based expert system to provide recommendations in the tourism domain. Expert systems with applications, 38(10), 13310-13319.

Gefen, D., Rigdon, E. E., \& Straub, D. (2011). Editor's comments: an update and extension to SEM guidelines for administrative and social science research. Mis Quarterly, 35(2), 3-14.

Geisser, S. (1974). A predictive approach to the random effect model. Biometrika, 61(1), 101107.

Ghose, A., \& Ipeirotis, P. (2006). Towards an understanding of the impact of customer sentiment on product sales and review quality. Information Technology and Systems, 12, 1-6.

Ghouri, A. M., \& Mani, V. (2019). Role of real-time information-sharing through SaaS: An industry 4.0 perspective. International Journal of Information Management, 49, 301315.

Goldenberg, J., Libai, B., \& Muller, E. (2001). Talk of the network: A complex systems look at the underlying process of word-of-mouth. Marketing letters, 12(3), 211-223.

Gordon, B. (1986). The souvenir: Messenger of the extraordinary. Journal of Popular Culture, 20(3), 135-151.

Gretzel, U. (2006). Consumer generated content-trends and implications for branding. Ereview of Tourism Research, 4(3), 9-11.

Gretzel, U., \& Yoo, K. (2008). Use and impact of online travel reviews. In P. O'Connor, W. Höpken, \& U. Gretzel (Eds.), Information and communication technologies in tourism 2008 (pp. 35-46). New York: Springer-Verlag.

Gretzel, U., Fesenmaier, D. R., Lee, Y. J., \& Tussyadiah, I. (2011). Narrating travel experiences: The role of new media. In R. Sharpley \& P. R. Stone (Eds.), Tourist experience: Contemporary Perspectives (pp. 171-182). New York: Routledge.

Hair, J. F., Risher, J. J., Sarstedt, M., \& Ringle, C. M. (2019). When to use and how to report the results of PLS-SEM. European Business Review. 31(1), 2-24.

Han, Y., Zhang, T., \& Wang, M. (2020). Holiday travel behavior analysis and empirical study with integrated travel reservation information usage. Transportation Research Part A: Policy and Practice, 134, 130-151.

Henseler, J., Hubona, G. and Ray, P.A. (2016). Using PLS path modeling in new technology research: updated guidelines. Industrial Management \& Data Systems, 116(1), 2-20.

Henseler, J., Ringle, C. M., \& Sarstedt, M. (2015). A new criterion for assessing discriminant validity in variance-based structural equation modeling. Journal of the Academy of Marketing Science, 43(1), 115-135.

Hollender, N., Hofmann, C., Deneke, M., \& Schmitz, B. (2010). Integrating cognitive load theory and concepts of human-computer interaction. Computers in human behavior, 26(6), 1278-1288.

Huang, Z., \& Benyoucef, M. (2013). From e-commerce to social commerce: A close look at design features. Electronic Commerce Research and Applications, 12(4), 246-259.

Jiang, S., Scott, N., \& Ding, P. (2015). Using means-end chain theory to explore travel motivation: An examination of Chinese outbound tourists. Journal of Vacation Marketing, 21(1), 87-100. 
Jung, J. H., Schneider, C., \& Valacich, J. (2010). Enhancing the motivational affordance of information systems: The effects of real-time performance feedback and goal setting in group collaboration environments. Management Science, 56(4), 724-742.

Kaplan, A. M. (2012). If you love something, let it go mobile: Mobile marketing and mobile social media 4x4. Business Horizons, 55(2), 129-139.

Kaplan, A. M., \& Haenlein, M. (2010). Users of the world, unite! The challenges and opportunities of Social Media. Business Horizons, 53(1), 59-68.

Kavoura, A., Bozyigit, S., \& Ozelturkay, E. Y. (2020). Turkish and Greek gift purchase behaviour and advertisement on traditional and online media communication tools based on gender differences. International Journal of Technology Marketing, 14(1), 1-21.

Kim, A. J., \& Ko, E. (2012). Do social media marketing activities enhance customer equity? An empirical study of luxury fashion brand. Journal of Business Research, 65(10), 1480-1486.

Kim, D., Kim, J. H., \& Nam, Y. (2014). How does industry use social networking sites? An analysis of corporate dialogic uses of Facebook, Twitter, YouTube, and LinkedIn by industry type. Quality \& Quantity, 48(5), 2605-2614.

Kim, S., \& Park, H. (2013). Effects of various characteristics of social commerce (scommerce) on consumers' trust and trust performance. International Journal of Information Management, 33(2), 318-332.

Kock, N. (2017). Common method bias: A full collinearity assessment method for PLSSEM. In H. Latan \& R. Noonan (Eds.), Partial Least Squares Path Modeling (pp. 245257). Cham: Springer.

Kudo, R., Enoki, M., Nakao, A., Yamamoto, S., Yamaguchi, S., \& Oguchi, M. (2019). Realtime event search using social stream for inbound tourist corresponding to place and time. International Journal of Big Data Intelligence, 6(3), 248-258.

Ladhari, R., \& Michaud, M. (2015). eWOM effects on hotel booking intentions, attitudes, trust, and website perceptions. International Journal of Hospitality Management, 46, 36-45.

Langmead, B., \& Nellore, A. (2018). Cloud computing for genomic data analysis and collaboration. Nature Reviews Genetics, 19(4), 208.

Lee, H. A., Law, R., \& Murphy, J. (2011). Helpful reviewers in TripAdvisor, an online travel community. Journal of Travel \& Tourism Marketing, 28(7), 675-688.

Lee, H. L., \& Whang, S. (2000). Information sharing in a supply chain. International Journal of Manufacturing Technology and Management, 1(1), 79-93.

Leung, D., Law, R., Van Hoof, H., \& Buhalis, D. (2013). Social media in tourism and hospitality: A literature review. Journal of Travel \& Tourism Marketing, 30(1), 3-22.

Li, F. S., \& Ryan, C. (2018). Souvenir shopping experiences: A case study of Chinese tourists in North Korea. Tourism Management, 64, 142-153.

Li, J., Xu, L., Tang, L., Wang, S., \& Li, L. (2018). Big data in tourism research: A literature review. Tourism Management, 68, 301-323.

Li, M., \& Cai, L. A. (2008). Souvenir shopping attitudes and behavior among Chinese domestic tourists: An exploratory study 中国国内游客购买旅游纪念品的态度及行 为研究. Journal of China Tourism Research, 4(2), 189-204.

Li, N., Tung, V., \& Law, R. (2017). A fuzzy comprehensive evaluation algorithm for analyzing electronic word-of-mouth. Asia Pacific Journal of Tourism Research, 22(6), 592-603. 
Li, X., \& Katsumata, S. (2020). The impact of multidimensional country distances on consumption of specialty products: A case study of inbound tourists to Japan. Journal of Vacation Marketing, 26(1), 18-32.

Li, X., Meng, F., \& Uysal, M. (2008). Spatial pattern of tourist flows among the Asia-Pacific countries: An examination over a decade. Asia Pacific Journal of Tourism Research, 13(3), 229-243.

Lim, Y. S., \& Heide, B. D. V., (2015). Evaluating the wisdom of strangers: The perceived credibility of online consumer reviews on Yelp. Journal of Computer-Mediated Communication, 20(1), 67-82.

Lipsman, A., Mudd, G., Rich, M., \& Bruich, S. (2012). The power of "like": How brands reach (and influence) fans through social-media marketing. Journal of Advertising Research, 52(1), 40-52.

Litirell, M. A., Baizerman, S., Kean, R., Gahring, S., Niemeyer, S., Reilly, R., \& Stout, J. (1994). Souvenirs and tourism styles. Journal of Travel Research, 33(1), 3-11.

Liu, Z., \& Park, S. (2015). What makes a useful online review? Implication for travel product websites. Tourism Management, 47, 140-151.

Lo, I. S., McKercher, B., Lo, A., Cheung, C., \& Law, R. (2011). Tourism and online photography. Tourism Management, 32(4), 725-731.

Lu, L. C., Chang, W. P., \& Chang, H. H. (2014). Consumer attitudes toward blogger's sponsored recommendations and purchase intention: The effect of sponsorship type, product type, and brand awareness. Computers in Human Behavior, 34, 258266.

Lu, X., He, S., Lian, S., Ba, S., \& Wu, J. (2020). Is user-generated content always helpful? The effects of online forum browsing on consumers' travel purchase decisions. Decision Support Systems, 137, 113368. https://doi.org/10.1016/j.dss.2020.113368

Lu, Z., Xia, H., Heo, S., \& Wigdor, D. (2018). You watch, you give, and you engage: a study of live streaming practices in China. Proceedings of the 2018 CHI Conference on Human Factors in Computing Systems, Canada, 1-13.

Ma, J. W., Yang, Y., \& Wilson, J. A. (2017). A window to the ideal self: a study of uk twitter and Chinese Sina Weibo selfie-takers and the implications for marketers. Journal of Business Research, 74, 139-142.

Mahmassani, H. S., \& Jayakrishnan, R. (1991). System performance and user response under real-time information in a congested traffic corridor. Transportation Research Part A: General, 25(5), 293-307.

Majchrzak, A., Faraj, S., Kane, G. C., \& Azad, B. (2013). The contradictory influence of social media affordances on online communal knowledge sharing. Journal of ComputerMediated Communication, 19(1), 38-55.

Malhotra, Y. (2005). Integrating knowledge management technologies in organizational business processes: getting real time enterprises to deliver real business performance. Journal of Knowledge Management, 9(1), 7-28.

Margherita, A. (2014). Business process management system and activities. Business Process Management Journal, 20(5), 642-662.

Maria-Irina, A. N. A., \& Istudor, L. G. (2019). The Role of Social Media and User-GeneratedContent in Millennials' Travel Behavior. Management Dynamics in the Knowledge Economy, 7(1), 87-104.

Martí, P., García-Mayor, C., \& Serrano-Estrada, L. (2019). Identifying opportunity places for urban regeneration through LBSNs. Cities, 90, 191-206.

Mkono, M., \& Tribe, J. (2016). Beyond reviewing: Uncovering the multiple roles of tourism social media users. Journal of Travel Research, 56(3), 287-298. 
Monteiro, V., Painho, M., \& Vaz, E. (2014). Is the heritage really important? A theoretical framework for heritage reputation using citizen sensing. Habitat International, 45, 156-162.

Murphy, L., Benckendorff, P., Moscardo, G., \& Pearce, P. L. (2010). Tourist shopping villages: Forms and functions. Routledge.

Kaosiri, N. Y., Fiol, C. L. J., Tena, M. A. M., Artola, R. M. R., \& Garcia, S. J. (2017). Usergenerated content sources in social media: A new approach to explore tourist satisfaction. Journal of Travel Research, 58(2), 253-265.

Nitzl, C., Roldan, J.L., \& Cepeda, G. (2016). Mediation analysis in partial least squares path modeling: Helping researchers discuss more sophisticated models. Industrial Management \& Data Systems, 116(9), 1849-1864.

O'Hara, K., Kindberg, T., Glancy, M., Baptista, L., Sukumaran, B., Kahana, G., \& Rowbotham, J. (2007). Collecting and sharing location-based content on mobile phones in a zoo visitor experience. Computer Supported Cooperative Work, 16, 11-44.

Özdemir, G., \& Çelebi, D. (2017). A social media framework of cultural museums. Advances in Hospitality and Tourism Research, 5(2), 101-119.

Park, O. J., \& Ryu, J. H. (2019). Cognitive fit effects of online reviews on tourists' information search. Information Technology \& Tourism, 21(3), 313-335.

Peter, J. P., Olson, J. C., \& Grunert, K. G. (1999). Consumer behaviour and marketing strategy. London: McGraw-Hill.

Pfiffelmann, J., Dens, N., \& Soulez, S. (2020). Personalized advertisements with integration of names and photographs: An eye-tracking experiment. Journal of Business Research, 111, 196-207.

Piccoli, G. (2016). Triggered essential reviewing: The effect of technology affordances on service experience evaluations. European Journal of Information Systems, 25(6), 477492.

Podsakoff, P. M., MacKenzie, S. B., Lee, J. Y., \& Podsakoff, N. P. (2003). Common method biases in behavioral research: A critical review of the literature and recommended remedies. Journal of Applied Psychology, 88(5), 879.

Presi, C., Maehle, N., \& Kleppe, I. A. (2016). Brand selfies: Consumer experiences and marketplace conversations. European Journal of Marketing, 50(9), 1814-1834.

Putrevu, S., \& Lord, K. R. (1994). Comparative and noncomparative advertising: Attitudinal effects under cognitive and affective involvement conditions. Journal of Advertising, 23(2), 77-91.

Reid, C. (2014). Real-time marketing can keep business successful - but how? Computer Information Science, 37(5), 6-10

Roma, P., \& Aloini, D. (2019). How does brand-related user-generated content differ across social media? Evidence reloaded. Journal of Business Research, 96, 322-339.

Shankar, V., Kleijnen, M., Ramanathan, S., Rizley, R., Holland, S., \& Morrissey, S. (2016). Mobile shopper marketing: Key issues, current insights, and future research avenues. Journal of Interactive Marketing, 34, 37-48.

Shin, S. Y., Van Der Heide, B., Beyea, D., Dai, Y. N., \& Prchal, B. (2017). Investigating moderating roles of goals, reviewer similarity, and self-disclosure on the effect of argument quality of online consumer reviews on attitude formation. Computers in Human Behavior, 76, 218-226.

Si, R., Arikawa, M., \& Shibasaki, R. (2017). Minimizing discontinuity in switching heterogeneous maps for mobile use. International Journal of Cartography, 3(1), 102120. 
So, K. K. F., Wu, L., Xiong, L., \& King, C. (2018). Brand management in the era of social media: Social visibility of consumption and customer brand identification. Journal of Travel Research, 57(6), 727-742.

Sparks, B. A., Perkins, H. E., \& Buckley, R. (2013). Online travel reviews as persuasive communication: The effects of content type, source, and certification logos on consumer behavior. Tourism Management, 39, 1-9.

Steward, M. D., Narus, J. A., \& Roehm, M. L. (2018). An exploratory study of business-tobusiness online customer reviews: External online professional communities and internal vendor scorecards. Journal of the Academy of Marketing Science, 46(2), 173189.

Stone, M. (1974). Cross-validatory choice and assessment of statistical predictions. Journal of the Royal Statistical Society, 36(2), 111-133.

Sui, D., \& Goodchild, M. (2011). The convergence of GIS and social media: challenges for GIScience. International Journal of Geographical Information Science, 25(11), 17371748 .

Sutanto, M. A., \& Aprianingsih, A. (2016). The effect of online consumer review toward purchase intention: A study in premium cosmetic in Indonesia. Proceedings of International Conference on Ethics of Business, Economics, and Social Science, 1(1), 219230.

Sweller, J. (1988). Cognitive load during problem solving: Effects on learning. Cognitive Science, 12(2), 257-285.

Sweller, J. (2020). Cognitive load theory and educational technology. Educational Technology Research and Development, 68(1), 1-16.

Tarver, E. (2019, September 24). Why the "Share a Coke" campaign is so successful. Investopedia Website. Retrieved January 3, 2020, from https://www.investopedia.com/articles/markets/100715/what-makes-share-cokecampaign-so-successful.asp

Taylor, S. A., \& Baker, T. L. (1994). An assessment of the relationship between service quality and customer satisfaction in the formation of consumers' purchase intentions. Journal of Retailing, 70(2), 163-178.

Tsiakali, K. (2018). User-generated-content versus marketing-generated-content: Personality and content influence on traveler's behavior. Journal of Hospitality Marketing \& Management, 27(8), 946-972.

Väätäjä, H. K., Ahvenainen, M. J., Jaakola, M. S., \& Olsson, T. D. (2013). Exploring augmented reality for user-generated hyperlocal news content. Proceedings of CHI'13 Extended Abstracts on Human Factors in Computing Systems, France, 967-972.

Vaittinen, T., \& McGookin, D. (2018). Uncover: supporting city exploration with egocentric visualizations of location-based content. Personal and Ubiquitous Computing, 22(4), 807-824.

Vessey, I. (1994). The effect of information presentation on decision making: A cost-benefit analysis. Information \& Management, 27(2), 103-119.

Wang, C., \& Zhang, P. (2012). The evolution of social commerce: The people, management, technology, and information dimensions. Communications of the Association for Information Systems, 31(5), 105-125.

Wang, Y. J., Doss, S. K., Guo, C., \& Li, W. (2010). An investigation of Chinese consumers' outshopping motives from a culture perspective. International Journal of Retail $\mathcal{E}$ Distribution Management, 38(6), 423-442. 
Wang, Y., \& Davidson, M. C. (2010). Chinese holiday makers' expenditure: Implications for marketing and management. Journal of Hospitality Marketing $\mathcal{E}$ Management, 19(4), 373-396.

Werthner, H., \& Ricci, F. (2004). E-commerce and tourism. Communications of the ACM, 47(12), 101-105.

Wiese, M., Martínez-Climent, C., \& Botella-Carrubi, D. (2020). A framework for Facebook advertising effectiveness: A behavioral perspective. Journal of Business Research, 109, 76-87.

Wilkins, H. (2011). Souvenirs: What and why we buy. Journal of Travel Research, 50(3), 239247.

World Tourism Organization (2018). UNWTO Tourism Highlights. Madrid, Spain: UNWTO.

Wu, J. Y., \& Xie, C. (2018). Using time pressure and note-taking to prevent digital distraction behavior and enhance online search performance: Perspectives from the load theory of attention and cognitive control. Computers in Human Behavior, 88, 244-254.

Wu, Z., Tian, L., Li, P., Wu, T., Jiang, M., \& Wu, C. (2018). Generating stable biometric keys for flexible cloud computing authentication using finger vein. Information Sciences, 433, 431-447.

Xiang, Z., \& Gretzel, U. (2010). Role of social media in online travel information search. Tourism Management, 31(2), 179-188.

Xiang, Z., Magnini, V. P., \& Fesenmaier, D. R. (2015). Information technology and consumer behavior in travel and tourism: Insights from travel planning using the internet. Journal of Retailing and Consumer Services, 22, 244-249.

Xu, Y., \& McGehee, N. G. (2012). Shopping behavior of Chinese tourists visiting the United States: Letting the shoppers do the talking. Tourism Management, 33(2), 427-430.

Ye, Q., Law, R., Gu, B., \& Chen, W. (2011). The influence of user-generated content on traveler behavior: An empirical investigation on the effects of e-word-of-mouth to hotel online bookings. Computers in Human Behavior, 27(2), 634-639.

Yilmaz, A. (2018). Yeni Bir Pazarlama İletişimi Yaklaşımı Gerçek-Zamanlı Pazarlama: Otomobil Markalarının Geleceğe Dönüş Günü Sosyal Medya Pratikleri. Erciyes İletişim Dergisi, 5(4), 423-446.

Yllmaz, E. (2020). The effects on consumer behavior of hotel related comments on the Tripadvisor website: An Istanbul case. Advances in Hospitality and Tourism Research, $8(1), 1-29$.

Yin, X., \& Li, J. (2021). Development of cultural tourism platform based on FPGA and convolutional neural network. Microprocessors and Microsystems, 80, 103579. https://doi.org/10.1016/j.micpro.2020.103579

Yoon, S. J. (2002). The antecedents and consequences of trust in online-purchase decisions. Journal of Interactive Marketing, 16(2), 47-63. 